\title{
From Progress to Happiness: Measurements for Latin America
}

\author{
Sary Levy-Carciente ${ }^{12}$, Luis Mauricio Phélan C. ${ }^{1}$, Jhoner Perdomo ${ }^{*}$ \\ ${ }^{1}$ Universidad Central de Venezuela, Faculty of Economic and Social Sciences, Ciudad Universitaria de Caracas, \\ Caracas, Venezuela \\ ${ }^{2}$ Boston University, Physics Department, Center of Polymer Studies, 590 Commonwealth Avenue, Boston, MA \\ 02215, United States
}

KEYWORDS

Development

Latin America

Metrics

Quality of life

Social indicators

\begin{abstract}
This paper is based on a transformed concept of development: from a concept of development that is single-dimensional, concrete, and mainly quantitative, into one that is multidimensional. We focus on the components of development, the measurement of which includes qualitative observations of its effect on final beneficiaries. Because a useful understanding of development policies requires an evaluation of all the different metrics that emerge, we evaluate the development indices of 19 Latin American countries. The most recent theoretical perspectives link development to both liberal philosophy - focusing on the many dimensions of human society and the fundamental rights of the individual - and utilitarianism - emphasizing an evaluation of the success of various development policies and the usefulness of their outcomes.
\end{abstract}

\section{Introduction}

Empirical evidence demonstrates that there is no direct relationship between economic growth, poverty reduction, and an improvement in the social wellbeing of a society. Most academics agree that economic growth does not necessarily lead to social development, and that rapid economic expansion

\footnotetext{
* Contact addresses: sary.levy@bu.edu (S. Levy-Carciente); mauphelan@gmail.com (L. M. Phélan C.); jhonerperdomo@yahoo.com (J. Perdomo)
} 
in a given country does not guarantee happiness or an increase in social wellbeing for its people (among others, see Kuznets 1955; World Bank 1991; Álvarez and Alonso 2006; Novales 2011).

Such evidence strongly suggests that our understanding of economic development is in the process of being transformed. The definition of development has evolved from one that is single-dimensional, concrete, aggregated, and primarily quantitative to one that is multidimensional, i.e., one in which discrete micro-components are measured and their qualitative effect on end beneficiaries given priority. A new effort to understand development from this multidimensional perspective is needed if we are to design public policies that produce scenarios that result in increased social wellbeing.

Adopting this broader concept of economic development and reviewing all the available metrics allows us to identify the metrics that could potentially function as early warning signs for changes in levels of social wellbeing. These metrics could also enable us to more effectively design public policies that encourage this wider, multidimensional form of development.

This paper is structured as follows: Section II expands on the broader concept and presents the different dimensions and their disaggregation by level or particularities. Section III presents a subjective analysis of the topic. Section IV presents a sampling of philosophical perspectives that could serve as a basis for policy implementation. Section V presents a study of metrics for Latin America. The final section presents some conclusions and final thoughts.

\section{Adding Dimensions and Disaggregating Components}

Earlier perspectives that used traditional economic indicators such as gross domestic product (GDP) and per capita world income assumed that global growth equalled prosperity. Because these indicators ignored deeper problems, e.g., inequality, their usefulness has been called into question. 
New indicators measuring conditions and variables at different levels of economic development have thus been proposed (Alaminos and López 2009; Levy-Carciente 2013). Although some of these new metrics are broader and some more specific, all of them are relevant.

The social development approach (Seers 1972; Chenery 1974) measures poverty, inequality, unemployment, and the role of institutions. It goes beyond traditional measurements and addresses the need to reduce inequality between and within nations. It includes measurements of the poverty line, critical poverty, unemployment, underemployment, minimum wage for a basket of basic goods, and the Gini coefficient.

Development programs with a broader multidimensional focus include Development with a Human Face (UNICEF) and Productive Transformation and Equality (ECLAC). These programs ameliorate social problems and also identify other elements in the World Bank's Comprehensive Development Framework (1998). Critiques associated with the progressive environmental deterioration and the diminishing nonrenewable resources were captured under the concept of Sustainable Development (Meadows 1972; Georgescu-Roegen 1971; Jacobs 1999; Mishan 1967; Ehrlich and Holdren 1971; Munasinghe 1993), which considered future generations as the beneficiaries of development projects.

The term Ecological Footprint was later coined to refer to the environmental cost as expressed in productive acres of land used to sustain one person. It is based upon the premise that nature can sustain development only if the economic activity does not exceed the regenerative capacity of the biosphere. It evaluates the impact that certain lifestyles have on the planet, compared to the planet's own biological capacity, thus becoming a key sustainability index.

This evolution in concepts, in which ethics is central to the analysis of the complexities of human social development, has received important theoretical contributions from Amartya Sen (1999) and Marta Nussbaum 
(2011). They speak of 'capabilities'1 and 'development as freedom' as providing a normative philosophical basis for a fundamental theory of human rights, an essential requirement for a dignified life with social justice. According to them, 'capability' or 'substantial freedom' is the essential element of development. The central players in their model are human beings, how they assess their quality of life, and how they are able to make proactive efforts to improve their wellbeing. From this perspective development does not refer to goods and services to which people have access, but rather to their ability to accomplish their goals in life. Thus the expansion of freedom is central to this approach.

The concept of human development examines how individual liberties are disrupted in countries undergoing economic development. Human development is defined as the quantity and quality of alternatives from which an individual can choose. The measurement of human development focuses on the probability that an individual in a given society (i) can have a long and healthy life, (ii) can acquire individually and socially valuable knowledge, and (iii) can obtain the resources that enable a life with dignity (UNDP 2011).

The Human Development Index (HDI) measures three dimensions associated with quality of life: life expectancy at birth, educational achievement, and adjusted income per capita. A scale of 0 to 1 is used to compute the average of these three components with a score of 1 indicating an ideal situation with a maximum number of human opportunities.

The HDI has been perfected and adjusted by disaggregating it into sub-populations, and incorporating aspects such as gender inequality (Gender-Related Development Index GRDI, Gender Empowerment Measure, GEM), poverty indices (Human Poverty Index for Developing Countries, HPI-1, Human Poverty Index for Industrialized Countries, HPI-2), freedom indices (Index of Human Freedom, IHF, Index of Political Freedom, IPF), and other

\footnotetext{
${ }^{1}$ Sen based his 'capabilities' theory on economic concepts to make a comparative analysis of the levels of quality of life for individuals in a society. Nussbaum on the other hand bases her theory on philosophical concepts, evaluating ethical implications for the construction of a free and plural society.
} 
elements that complement this analysis (International Responsibility Index for Human Rights, and Technological Progress Index).

Tobin and Nordhaus have developed a metric called Measures of Economic Welfare (MEW) (Daly and Cobb 1994). It adjusts economic results affected by environmental externalities using a correction for urban inconvenience.

Daly and Cobb (1994) created an Index of Sustainable Economic Welfare (ISEW) that adjusts economic results using environmental damage, extinction of non-renewable natural resources and income distribution.

One of the first indicators that include the social dimension in its metrics is the Physical Quality Life Index (PQLI) developed by Morris (1979). Rather than measuring development, it intended to measure social wellbeing defined as the material conditions required for individual integral development. Conditions such as food, health, housing, and education, among others form part of this index. The PQLI is calculated as the weighted average of three indicators: infant mortality, life expectancy at one year of age and adult literacy rate.

The Basic Capacity Index (BCI) is an alternative index developed by Social Watch (based on a life quality index developed for Action for Economic Reform for Social Watch in the Philippines). It is inspired by the poverty of capacities measurement proposed by Amartya Sen. It adds through income, to the economic dimension indicators of the population's different health and education capacities associated with social development. The BCI is calculated using three dimensions: education, health and sexual and reproductive health. A score close to 100 means 'dignifying conditions for all' as proclaimed by the Universal Declaration of Human Rights and indicates compliance with fundamental social rights, thus becoming a starting point for the pursuit of social welfare objectives.

The Gender Inequality Index (GII) measures the disadvantages that women face through three dimensions: sexual and reproductive health (maternal mortality rate and teen pregnancy rate), female empowerment (rate of secondary education among women and their participation in 
Congress, relative to men), and the labour market (participation of women in the labour force compared to that of men). GII is associated to HDI in that they both reflect the loss in human development caused by the existing inequality between the achievements of women and the achievements of men in the dimensions described. It ranges between 0 and 1 , where 0 indicates equal development among genders and 1 indicates that women's performance at these indicators is worse than men's.

Based on the ISEW, Breslow developed the Genuine Progress Indicator (GPI), which considers the total costs and benefits of production. Data show a decreasing tendency in progress since the 1970s. It uses 26 social, economic and environmental variables, condensed in 6 variables. It is calculated as follows: internal private consumption (adjusted for economic inequality) plus time spent on unregistered and unpaid activities (home, voluntary or community services), plus public expenditure, minus security and defence expenses, minus social cost derived from environmental degradation minus devaluation of natural capital (Talberth, Cobb and Slattery 2007).

The World Bank has developed a Wealth Index that evaluates the level of wealth among the different nations, considering human capital one of the elements.

The Economic Freedom Index (EFI), created by The Heritage Foundation (Miller and Holms 2011), ranks 183 countries according to 10 parameters that measure the degree of freedom, a basic ingredient for development. These parameters are: economic freedom, international trade freedom, fiscal liberty, monetary freedom, freedom to invest, financial freedom, size of the State, property rights enforcement, level of corruption and freedom to work. The index ranges from 0 to 100 .

The central emphasis that EFI places on capitalism has been criticized by those who do not share capitalism's value system. This has led to the formation of Economic Freedom of the Rest of Us (EFRU), which measures the impact of government policies, rules and institutions on the economic performance of members of society who need to work for a living. This index is calculated using 20 economic variables that are grouped in 13 
components and summarized in three final categories: freedom from exclusion or Employment (measured by the level of employment, level of unemployment and time of unemployment); freedom from hunger or Income (measured by the average wage, productivity and minimum wage); and freedom from discrimination and fear or Equality and Security (measured by the equality of income distribution, the difference of income by gender, the income gap between hourly employees and full time workers, the poverty rate, the public expenditure per capita on social programs, social assistance and employment stability) (Stanford 1999).

Given the relevance of institutions and the respect for rule of law to promote economic activity to foster development, the role of the private sector emerges as a key element to achieve social welfare. However, if corruption proliferates and institutions are weak, the relationships of trust, upon which economic activity depends, are placed at risk along with social stability at every scale; from international relations to community relations, from the market to governments. In consequence, development opportunities are jeopardized.

Organizations such as Transparency International have developed some indices that combine qualitative and quantitative aspects, macro indices, specific diagnostics, objective components and subjective perceptions, to evaluate the impact of different policies, identifying risks and proposing alternative strategies. Among these indices are:

- Corruption Perception Index (CPI): defines corruption as the abuse of power (public and private) for personal purposes. The index captures the perception of corruption in the public sector of different countries. It is based on surveys of companies and experts on corruption and government best practices. It ranges from 0 to 10 . A grade of 10 being a country whose perception of corruption is the lowest of all.

- Bribe Payers Index (BPI): This index ranking is based on surveys of executives. It classifies 30 of the main exporting countries and looks for the probability that their companies could have incurred bribing actions abroad. 
- Global Corruption Barometer (GCB): Annual survey of households looking for their perceptions and experiences related to corruption.

- National Integrity System Studies (NIS): Produce a diagnosis of strengths and weaknesses of key institutions that should constitute an example of best practices and national integrity.

- Global Corruption Report: Though a themed focus, this instrument analyzes corruption with respect to a specific, current, and relevant sector or governability issue.

Martin Krause (CIIMA and ESEADE), has developed the Institutional Quality Index. It is based upon the argument that economies with stronger individual rights show more respect for civil liberties, have higher growth rates, and better opportunities.

The Freedom Press Index, elaborated by Reporters without Borders, measures the degree of freedom that journalists and the media have in every country. It also considers the actions that governments implement to guarantee the existence of freedom of the press. The classification is made through a complementary indicator calculated on a yearly basis. It does not take into consideration human rights violations, but rather specific attacks to freedom of the press. Data is collected though a questionnaire of 43 items in topics such as: attacks against journalists or media, impunity, selfcensorship, economic pressures, judicial frame, and independence level. Ranking starts at 0 , which reflects the greatest freedom of the press, and increases when conditions for freedom of the press are violated.

The link between the government system and development is yet a different angle that is worth reviewing. However, the relationship between democracy and income per capita is not determinant, as the hypothesis is demonstrated only $30 \%$ of the time. It is also worth noting that when extracting oil-exporting countries from the sample, the correlation increases to $60 \%$. As a consequence The Economist Intelligence Unit created the Democracy Index, where democracy is defined as the principles and practices that institutionalize and protect freedom. This index captures the state of political and civil liberties. It is calculated using 60 indicators grouped in five 
correlated categories: pluralism and electoral process, civil liberties, government performance, political participation, and political culture. From these measurements emerge four types of regimes: full democracies, flawed democracies, hybrid regimes and authoritarian regimes.

The Global Innovation Index by INSEAD eLab recognizes the importance of innovation for economic growth and prosperity. It serves as a tool to facilitate public-private interaction where policy-makers, business leaders and other actors can continually evaluate progress. It has $2 \mathrm{sub}$ indices: one for input which captures 5 elements of the national economy that stimulate innovation activities: 1) institutions, 2) human capital and research, 3) infrastructure, 4) market sophistication and 5) business sophistication. The other sub-index is one of product innovation and has two pillars that capture innovation outcomes: scientific outcome and creative outcome.

The Prosperity Index, developed by the Legatum Institute, measures prosperity as a result of happiness, health, and freedom of the people. It aggregates 89 variables grouped in 8 sub-indices that have demonstrated an impact on wealth and welfare. They are: economy, entrepreneurship and opportunity, governability, education, health, security, personal freedom and social capital. The weight of each sub-index results from a statistical analysis.

The Globalization Index, developed by the KOF Swiss Economic Institute, presents the creation of complex and interdependent networks between actors in different parts of the world, through migration, flow of information, flow of ideas and movement of capital, goods and services. The index considers three dimensions: the economic dimension that looks at the flow of goods and capital as well as mobility restrictions; the political dimension that looks at diplomatic connections, subscribed agreements and international organizations that the country is a part of; and the social dimension that looks at different means to establish personal contact, access to information and cultural proximity. The social dimension has a participation of $37 \%$, followed by the economic dimension that has a 
participation of $36 \%$, and finally the political dimension with a participation of $26 \%$. The index ranks from 0 to $100 \%$, the latter being the value for the greatest level of globalization for a country.

The Fund for Peace, an NGO that promotes sustainable security and prevention of violent conflict, has developed the Failed State Index. It classifies countries according to their inability to control their own geographical territory, availability of basic services to their population, and economic and ethical degradation at every level of society. The index considers twelve elements: two economic, four social and six political. The elements are: unequal development, economic crisis, demographic pressure, migration of refugees and displaced population, unhappiness and search for retaliation, massive and permanent population runaway, criminalization and State illegitimacy, public services deterioration, human rights violations, para-State security organizations, divided elites, and foreign intervention. The scale has four levels: Alert (red), Warning (orange), Moderate (yellow) and Sustainable (green).

In addition to the indices mentioned above, a substantial amount of indicators have emerged with the purpose of understanding essential dimensions of development and people's quality of life.

\section{From Objective to Subjective Thinking}

While revising the concept of development, its scope and its characteristics, two simultaneous roads are transited: one that goes from its macrodeterminants to the micro components; and the other, in which the evaluation performed uses qualitative perceptions rather than quantitative indicators, focusing on deviations rather than average behaviors, and on individual perceptions rather than on a national or regional array.

Hence, the analysis must involve different elements, and the evolution of its focus from progress through growth to development lead to concepts such as welfare, quality of life, satisfaction and happiness. The concept of Small is Beautiful has taken over the discussions as the macro-picture has 
been replaced with perceptions of its results: the micro-social picture.

One of the main predecessors of this concept is Manfred Max-Neef's Human Scale Development (1993), created with a micro-perspective and subjective thinking. It aims to understand the economic system's structure and dynamics focusing on human basic needs. Its frame of analysis includes institutional and ecological dimensions, dynamics that emerge from social groups and their cultural scene. It establishes as its fundamental pillars: human needs, self-dependency, and organic articulations, for which it is required to empower individuals and give them independence from paternalistic states as well as deepen democracy.

Max-Neef defines a matrix that includes human needs - not only absences but also potentialities - and existential categories. The needs included are: subsistence, protection, affection, understanding, participation, leisure, creation, identity and freedom. The existential categories included are: being (qualities: personal or collective attributes), having (things, institutions), doing (actions), and interacting (settings: environment and surrounding). A dynamic relationship derives from this matrix, which presents the current state as well as the desired state. These, when integrated, define action strategies.

Human Scale Development focuses development goals into their own process of accomplishment. It turns them into their driver and combines synergy and efficiency for their achievement.

New Economy Foundation (NEF), on the other hand, has elaborated a Happy Planet Index, HPI (Murphy 2009), highlighting ecological efficiency, a driver of quality of life. Despite its name, its objective does not consist of giving an indication of happiness among the people in a country. Rather, it intends to show the way countries are able to utilize natural resources to provide quality of life to its citizens. It is calculated using three dimensions: hope for life, satisfaction and ecological footprint (relationship between quality of life and natural resources used).

One of the most relevant aspects of the HPI has to do with the satisfaction component, originally measured using various data that served 
as proxy for this concept. Nowadays it is calculated using the results from the World Survey by Gallup, a survey conducted in 112 countries. The scope is increased when using the surveys developed by World Values Surveys Association (WVSA), a network of social scientists who study the change of values and its impact in social and political life. In addition, WVSA, together with European Values Studies (EVS) have launched five global surveys between 1981 and 2007 to monitor changes.

Addressing the challenge to make governments accountable on environmental issues, in 2006 the Environmental Performance Index, EPI, was developed. The EPI is an aggregated index developed by Yale University specifically by the Yale Center for Environmental Law and Policy, with support from the Center for International Earth Science Information Network of Columbia University - in collaboration with other European institutions. EPI focuses its analysis on two objectives: reducing environmental stress on the health of the people and promoting the vitality of the ecosystem and natural resources' management. EPI makes an analysis of 132 countries with 22 performance indicators spanning 10 policy categories, which respond to two major objectives such as: environmental public health and ecosystem vitality. Each indicator is associated with environmental public health and sustainability of ecosystem objectives. The 10 categories the EPI works with are the following: Environmental Health, Water (including effects on human health and the ecosystem), Air Pollution (including effects on human health and the ecosystem), Biodiversity and Habitat, Forests, Fishing, Agriculture and Climate Change.

Veenhoven $(2007,2009)$ has developed an approximation to combine life satisfaction with life expectancy, or the so-called Happy Life Years, HLY. It captures objective elements and subjective welfare elements. This life elongation concept must be combined with its quality in order for life to become satisfactory. According to Veenhoven, happiness is the subjective appreciation of our own life, or in other words, how much we like our own life.

Calculations to derive this index are: 
Expected Satisfaction $(\mathrm{t})=$ Gallup $(\mathrm{t}) *$ WVS $(\mathrm{t}-\mathrm{n}) / \mathrm{WVS}(\mathrm{t})$

Happy Life Years $(t)=$ Life Expectancy $(t) *$ Estimated Life Satisfaction $(t)$ Happy Planet Index $(t)=($ Happy Life Years $(t) /$ Ecological Footprint $+a) * \beta$; where $\alpha=3.35 ; \beta=6.42$

Another interesting index is the Index of Life Satisfaction, which measures happiness as an alternative to traditional measurements. It is calculated using a series of surveys performed by the firm Gallup on the perception of Life Satisfaction, an aspect of welfare. It encompasses individual perceptions of feeling well, with an individual sense of vitality, the opportunities to pursue attractive and meaningful activities that stimulate feelings of competence and autonomy, and the acquisition of internal resources that allow us to face difficult situations.

From a systemic paradigm, influenced by the Buddhist culture, emerges a more holistic development perspective: the concept of Gross National Happiness. Proposed by Bhutan's king, Jigme Singye Wanchuck, GNH highlights the human dimension and ties itself to cultural values. It believes that material growth alone threatens cultural heritage. This theory argues that the true human development is based on complementarity and reinforcement of material and spiritual development.

GNH was developed jointly with UNDP and it is a measurement of a qualitative condition based on four pillars: promotion of socio-economic, sustainable and equalitarian development, preservation and promotion of cultural values, environmental conservation and establishment of a good government. These pillars are derived from nine dimensions: psychological wellbeing (evaluates the degree of satisfaction and optimism at a personal level using indicators such as stress, spiritual activities and positive emotions); health (considers the effectiveness of health policies using individual criteria such as sleep, exercise, nutrition, risky behavior); time management (recreation, socializing, education, traffic); community vitality (interpersonal trust, sense of belonging, voluntary activities); education (capacity and skill development, values); culture and resilience (tradition, 
development of artistic skills); environment (quality of air, soil, water, biodiversity); governance (acceptance of the government, the media, justice, the electoral system, participation, transparency, responsibility); and living standards (family income, financial security, level of endowment, and labor security among other).

From another part of the world and with different cultural roots, emerges the concept of Buen Vivir or Good Living (Sumak Kawsay in indigenous Ecuadorian Quechua or Suma Qamaña in indigenous Bolivian Aymara). It is based on the Andean worldview, and includes the idea of welfare and nature as a subject of rights in harmonic coexistence. The concept defines schemes of individual, community and environmental development. As it is expressed in Ecuador's National Plan:

'Good Living... expands rights, liberties, opportunities and potentialities of human beings, communities, towns and nationalities and guarantees recognition of diversity to attain a shared future' (SENPLADES 2009: 33).

The concept is still in the process of identifying dimensions and mechanisms to measure elements to be incorporated. It intends to capture the demands and innovations that indicators have exhibited throughout the $20^{\text {th }}$ and beginning of the $21^{\text {st }}$ century:

'The construction of Good Living indicators must acknowledge that indicators are created to respond to national perspectives of States or from the subject, of their perception of quality of life and wellbeing. It is therefore required to consider both angles: homes and communities, or micro components; and nation and religion, or macro components' (Phélan 2011).

Venezuela has also developed the principle of Supreme Social Happiness, found in the First Socialist Economic and Social Development Plan, PPS, 2007-2013 (RBV, Nov. 2007). It relates content-wise with the new perspectives described, however it is not elaborated to characterize it.

However, this alternative perspective has an antecedent in Venezuela: the South Commission's initiative conformed by world renowned authors such as Max-Neef, Dharam Ghai, Mahbub ul Haq, Meghnad Desai and 
Hazel Henderson. This commission proposes to redefine development to give it a social and humanitarian character, for which it was suggested to find more effective social indicators as well as the creation of a Social Welfare Index (Comisión Sur 1989).

In 1989, supported by the Venezuelan President, the South Commission met in Caracas to establish basic agreements between developing countries in order to test actions according to the countries' own conditions and capacities. Among their recommendations, they made some methodological ones which advised for the compilation of simple and easyto-understand social indicators, rather than creating new indices or using indices resulting from the combination of existing ones. Such indicators needed to serve as guidance for policy and decision-making and needed to be as disaggregated as possible so as to visualize particularities of groups and specific sectors of society (women, informal, regions and other).

\section{The Pursuit of Happiness as a Public Policy Objective}

One of the many valuable inputs of Sen (1999) and Nussbaum's (2011) work was to reintroduce in the topic of development and welfare metrics, a concept that is intrinsically relevant for people: individual freedom, as the end and as a means to pursue social justice or a dignifying life.

Sen's development theory related to the expansion of substantial freedom, forces the eradication of its barriers (poverty, tyranny, public negligence, intolerance, social deprivation, among other). Simultaneously it demands overlapping institutionalism with a complex system of instrumental liberties (political freedom, economic freedom, social opportunities, transparency and protective security).

The above statement is formulated in individual terms as it argues that the different levels of aggregation (family, community, and nation) could hide significant distortions.

Nussbaum, on the other hand, identifies ten capabilities for a dignifying life: life, health, corporal integrity, sense of imagination and 
thinking, emotions, practical reason, affiliation, games, and control over the environment. These essential capabilities are a collective responsibility from which institutionalism emerges to guarantee social justice. Its design demands individual participation and cooperation. From such social interaction emerges a socially valuable component to transform resources into empowering elements, or capacities, for individuals. Furthermore, the author defends the existence of liberties and respect for cultural diversity.

This theory is not evaluated by results or accomplishments, nor is it assessed by individual's perceptions of their own accomplishments. Instead, it is evaluated by socially available capabilities that allow for a better individual performance. As a result, this perspective can be identified in the liberal democracy tradition².

Concepts like Happy Planet, Gross National Happiness, Happy Life Years and Good Living evoke utilitarian perspectives. Measurements of success of these indicators focus on the usefulness of its consequences, that is, on the assessment of what is intrinsically relevant to individuals and at a common ground where the utilitarian doctrine and the concepts of pleasure and happiness are related.

Helvetius, Beccaria, Priestley, Mill, Stuart Mill and Bentham constitute historical references of utilitarianism, the latter being recognized as the father of this philosophical and ethical perspective. In his book $A n$ Introduction to the Principles of Morals and Legislation, Bentham defined the principle of utility as:

'that principle which approves or disapproves of every action whatsoever. According to the tendency it appears to have to augment or diminish the happiness of the party whose interest is in question' (Behtham 2000 [1781]: 14).

In addition, Society's interest resulted from the sum of individual pleasures less the total pain and affliction. He argued that we should seek 'maximum happiness for the greatest number of people' (Bravo 2000).

\footnotetext{
2 Within the liberal framework, while Rawls focuses on fair distribution of primary goods, Nussbaum focuses on fair distribution of 'capabilities'.
} 
In The Utilitarianism (1863), J.S. Mill argues that 'happiness is desirable and it is only desirable as an end, being the rest of things only desirable as a means to that end'. He states that this criterion for the pursuit of happiness is not an individual objective but a social one. His work includes a qualitative division of pleasures, arguing that moral and intellectual pleasures are greater than physical ones. He also makes a distinction between happiness and satisfaction, the first one being of higher value. His theory on the two manifestations of utilitarianism, act and norm, constitutes an important contribution. The act manifestation indicates that every time one executes an action one must consult one's internal judgment in order to produce the maximum amount of happiness. The norm manifestation argues that judgment must depend on rules.

The norm manifestation could serve as guidance for public policy, particularly if it contemplates as an objective the pursuit of happiness among the individuals in a society. Such task should consider transformations, expansion and new perspectives and assessments of the concept of development.

Let us remember that utilitarianism has been a subject of critiques throughout history. The most well-known is Kant's, who confronted it against its moral imperative (which states that the person must always be the end of the action and not the means). Even though happiness is the only end, the person would become a means for its pursuit. As long as happiness is an internal and subjective good, and only perceived by a unique subject, utilitarianism brought to an extreme is compared to selfishness. Therefore, in order to avoid selfishness, we must recognize the need to objectify the good, giving it the character of a collective good.

Likewise, Rawls argues that the principles of utilitarianism condemn the socially less favored individuals to social sacrifice, depriving them from the right to complain. In his Theory of Justice he rejects these principles and proposes the principle of difference or maximum. This principle allows the maximization of a social position for the least favored without putting at risk the privileges of the most favored, thus encouraging social cooperation. 
The evolution of development indicators and the abundance of indicators that measure individual perceptions of their quality of life, welfare and happiness indicate a tendency where subjective concepts will be considered public policy goals in different countries as well as globally.

In 2008 French President Nicolas Sarkozy requested an economic development measurement from a commission integrated by Stiglitz, Sen and Fitoussi. The measurement consisted of calculating progress using the most relevant indicators to show the impact that current public policy has on people's welfare. The commission completed the report and gave their final recommendations (Stiglitz, Sen and Fitoussi 2010). Likewise, British Prime Minister David Cameron requested that the National Statistics Bureau, in November 2010, conduct a survey about happiness among the British people, which was used as an input for making policy adjustments. These initiatives represent concrete examples of conceptual progress of subjective evaluation indicators of welfare and happiness (Mars, 2010).

It is somewhat paradoxical that critiques of unequal distribution focused on economic aspects of rational policies are derived precisely from the liberal philosophy and utilitarian perspective of maximum possible happiness. And that concepts derived from such critiques serve as guidance for public policy, especially since liberalism and utilitarianism have been related to individual selfishness, an element that has been criticized in development schemes and political consensus of the 20th century.

In this sense, it is worth rescuing these philosophical and theoretic perspectives in which the individual emerges after years of being diluted in aggregations such as community, society or nation.

Likewise, it leads us to define new structures so that not only these concepts can be specified and performed, but also to make sure that the effects of their political action do not generate new distribution failures or asymmetries. Also, it compels us to give the values of justice and freedom the higher priority, along with the satisfaction of material needs. 


\section{Some Indices for Latin America}

As it was explained before, the inclusion of different dimensions into the concept of development has been associated with a set of metrics in order to explain, compare, evaluate and analyze their conduct or performance.

Each one of these metrics identifies elements that must undoubtedly be present when speaking about development. However, each metric by itself cannot capture the scope of the concept, nor can it capture its systemic and dynamic character.

This idea is reinforced by Sen and Nussbaum's approach on the importance of capabilities extension, also defined as substantial freedom. It motivates us to present and analyze a set of indices across different dimensions that explain, to some degree, the multidimensionality of the concept of development and its relationship with the population's welfare and quality of life.

Two aspects are considered: the first one refers to potentialities (basic needs conditions); the second one refers to derivations from potentialities' synergic combinations, related to quality of life that people enjoy in every country.

Potentialities are divided into two categories: metrics that capture human and natural capabilities of a given country, and metrics that capture opportunities that the country's national institutions offer to society. It is assumed that the synergies that promote a better and sustainable quality of life are derived from the efficiencies of the combination of the two.

Capabilities were evaluated using the Human Development Index (HDI), the Gini Coefficient ${ }^{3}$, and the Environmental Performance Index (EPI). Since HDI includes aspects associated with health, education and income, and the Gini Coefficient illustrates the degree of income inequality, these two indices indicate human possibilities within society. The EPI index

\footnotetext{
3 The Gini Coefficient measures the degree of inequality in family income distribution of a country. It is calculated using the Lorenz curve, in which accumulated income is expressed graphically against the number of homes organized from the wealthiest to the poorest. The lower the Gini coefficient, the greater the equality of income distribution.
} 
relates to environmental wellbeing and ecosystem vitality, both of which are necessary to meet current and future demands of the population.

Opportunities were evaluated using institutional conditions, the rule of law (such as laws, norms, organizational rules, etc.) and for the analysis we considered: freedom of political action, freedom of expression, freedom to satisfy material needs, respect for diversity, otherness, and respect for rules and norms established. The following indices were used to assess these values: Democracy Index (The Economist), Press Freedom Index (Reporters without Borders), Index of Economic Freedom (Heritage Foundation), Gender Inequality Index (UNDP) and Corruption Perceptions Index (Transparency International).

The Synergic Efficiency, on the other hand, was evaluated using the following indices: Individual Satisfaction (Life Satisfaction Index, by Gallup), Collective Satisfaction (Prosperity Index, by Legatum), Technological Progress (Global Innovation Index), Environmental Sustainability (Happy Planet Index), and Global Interconnectedness (Globalization Index).

The hypothesis that guides the present research is based on the idea that different countries of Latin America, although having common historical and cultural roots, have strong differences from a multidimensional perspective in their level of development. Due to this, the research aims to compare the dimensions that make up the development or progress of the region in order to identify those factors that allow some countries to achieve better conditions and opportunities for their inhabitants. This way, countries that have more opportunities are those who manage to best leverage their potential to be transformed into results. This exploitation is achieved in a symmetrical and harmonious way among the different dimensions (indices and their respective indicators). Conversely countries having an asymmetric or irregular behaviour in those different dimensions lessen their potential and therefore the results are lower, to the detriment of its inhabitants.

The purpose of this work is to combine all of these indices in a 
principal components analysis, PCA. We aim to synthesize the different interactions into specific factors that show the performance of selected countries. This exercise allows us to characterize and group together countries with similarities in their indices, as well as to create new aggregated variables through these factors.

The comparison of the selected indices is more than simple statistical comparisons of the results for each country, and below are some important aspects that should be considered when reading the results. First, the study is based on concepts and approaches that have their numerical expression in each index, using the best indicators selected by us associated with the aim of the study and prepared by international institutions. In this way we seek to combine the Human Development, Progress, Inequality by gender, Press' Freedom and Ecological efficiency, among others, correlating results of their numerical expression and not of their internal composition, since we want statistical comparison of the results of the indices for each country, to observe the heterogeneity of the region and the differences with a PCA. Our intention is not to provide a new set of indicators, but to show how existing information can be used to evaluate the development, without disaggregating the indices. Second, although there are similar dimensions in some indices, most are composed of different indicators. It is for example the case of the economic dimension, where the indicator of the Human Development Index is the Gross Domestic Product (GDP); while the Prosperity Index, contains 15 indicators, including the Gross Domestic Savings. There are also disparities within the same dimension between indices, as some are composed of larger amounts indicators than others, so the relative weight of each indicator is different. In some cases indicators represent access, elsewhere results. Some are objective and others are subjective measures of quality or perception. Third, indicators within the same dimension are not necessarily associated or correlated among them. Fourth, even in the case where the indicator used is the same, as it is the case of Life Expectancy in Human Development Index, Happy Planet Index and Prosperity Index, the correlation between HPI and HDI is low, while between HDI and PI it is 
higher. Even if covariance between indicators could exist, due to their complexity, empirical data show that it is really low. What happens is that the calculation of each index is different and the indicator in each case has a different weighting and treatment. The method of aggregation of the HDI is through averages while the PI it is by weighted averages, adding variables with analysis of PCA and weights are assigned using regressions. Another issue is the multidimensionality of the index: unlike the HDI, the PI is an aggregate composition of 89 indicators. However, there may still be some mechanical covariance, which could tempt one to use disaggregated indices, but adding more information could lead to inconsistencies. For the previous reasons, the used indices do not align directly in their construction and composition, therefore not skewing the results of the analysis. Each index has a different role that responds to the concept that we want to measure and the importance of the analysis involved is to highlight these similarities or differences for the region.

The study considers the 13 metrics mentioned above for 19 countries in the Latin American region (see Table 1). The most recent data available (data from 2009 to 2014) was used for the calculations. It is worth mentioning that the difference in the years of the data was considered irrelevant given that variations of each index in the short term are marginal. In the case of Cuba's non-existent values for three of the chosen indices, we decided to impute them by the median method, as the best option.

Prior to conducting the analysis, the direction of the indices was adjusted to make sure that they all pointed the same way. The fact that the Gini Coefficient's 'positive'4 measurement occurs when values are closer to zero (0), and the HDI's 'positive' measurement occurs when values are closer to one (1) justify the importance of making this adjustment. As a result, when analyzing the aggregated indices we can obtain coherent values despite the disparity across the 19 countries. The direction of all variables was therefore transformed into 'positive' and increasing, starting at zero (0). Likewise, the scale of measurement of all indices was homogenized to avoid

\footnotetext{
${ }^{4}$ Positive: indicates better behaviour of indices.
} 


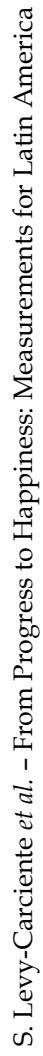

\begin{tabular}{|c|c|c|c|c|c|c|c|c|c|c|c|c|c|c|c|c|c|c|c|c|}
\hline \multirow{5}{*}{ 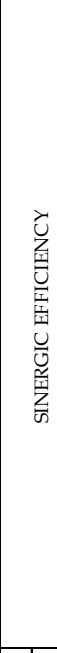 } & & & 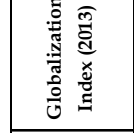 & $\mid \begin{array}{l}\infty \\
\infty \\
\infty \\
i \\
i\end{array}$ & 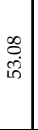 & \begin{tabular}{c|c}
7 \\
\multicolumn{3}{c}{} \\
\end{tabular} & S. & 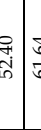 & $\begin{array}{c}0 \\
\dot{c} \\
\dot{c}\end{array}$ & 施 & $\begin{array}{l}\text { ते } \\
\text { पे }\end{array}$ & $\begin{array}{l}0 \\
0 \\
\circ \\
\text { in }\end{array}$ & $\mid \begin{array}{l}8 \\
8 \\
0 \\
0\end{array}$ & 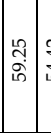 & $\begin{array}{l}7 \\
7 \\
i\end{array}$ & & 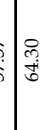 & 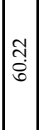 & 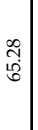 & $\mid \begin{array}{l}\not{F} \\
\dot{\alpha} \\
\dot{q}\end{array}$ \\
\hline & & & 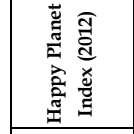 & Fi & $\begin{array}{l}0 \\
\stackrel{9}{q} \\
\dot{q}\end{array}$ & 고ํ & îें & 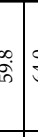 & 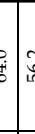 & 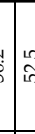 & $\mid \begin{array}{l}\infty \\
\infty \\
\infty \\
i n\end{array}$ & 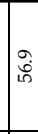 & 宫 & î & 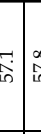 & & •. & 空 & 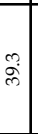 & $\mid \begin{array}{l}a \\
\dot{b} \\
\text { in }\end{array}$ \\
\hline & & & 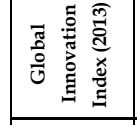 & 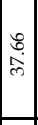 & 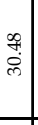 & 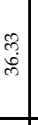 & 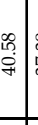 & $=$ & & 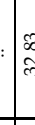 & 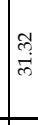 & 离 & 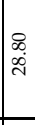 & $\mid$ & 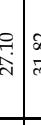 & & $\begin{array}{c}0 \\
\vdots \\
\vdots \\
\vdots\end{array}$ & $\begin{array}{l}\infty \\
0 \\
\cdots \\
0 \\
0\end{array}$ & 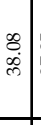 & 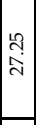 \\
\hline & & & 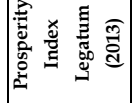 & : & 它 & : & $\stackrel{9}{\rightarrow}$ & 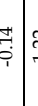 & $y$ & $\frac{7}{1}$ & 袋 & 帒 & $\mid \begin{array}{c}\infty \\
\substack{i \\
i}\end{array}$ & $\mid \begin{array}{l}0 \\
0 \\
0 \\
i\end{array}$ & 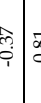 & $\begin{array}{l}0 \\
0 \\
0 \\
\end{array}$ & : & & 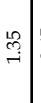 & $\mid \begin{array}{l}q \\
⿱ 亠 䒑 \\
i\end{array}$ \\
\hline & & & 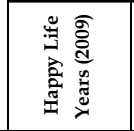 & $\mid \begin{array}{l}\mid r \\
\text { E. }\end{array}$ & | & : & 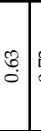 & $\stackrel{8}{8}$ & 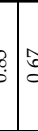 & 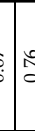 & 苛 & 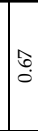 & 芯 & 奋 & 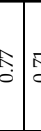 & 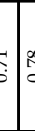 & : & 宓 & 㐘 & 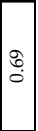 \\
\hline \multirow{5}{*}{ 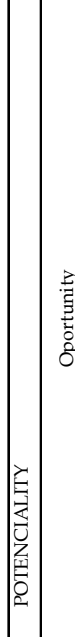 } & \multirow{5}{*}{ 童 } & 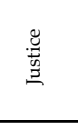 & 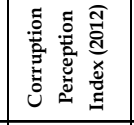 & $\stackrel{8}{m}$ & से & q & $\approx$ & $\infty$ & $\ddot{n} \stackrel{\infty}{+}$ & 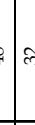 & $\infty$ & $\infty$ & $\stackrel{\infty}{\sim}$ & 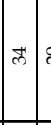 & ते & 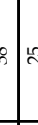 & 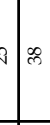 & $\stackrel{\rho}{m}$ & 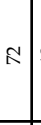 & $\approx$ \\
\hline & & 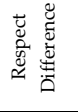 & 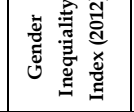 & $\mid \begin{array}{c}\infty \\
\infty \\
0 \\
0 \\
\end{array}$ & $\stackrel{f}{\stackrel{f}{0}}$ & I & 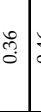 & 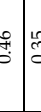 & 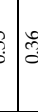 & F & F & 莗 & 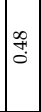 & {$\left[\begin{array}{lll}\infty \\
0 \\
0 \\
0\end{array}\right.$} & $\begin{array}{lll}0 \\
0 \\
0\end{array}$ & O & t: & 离 & 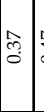 & fr \\
\hline & & 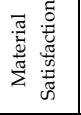 & 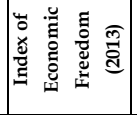 & s. & $\begin{array}{l}\overrightarrow{2} \\
\overrightarrow{+}\end{array}$ & 离 & 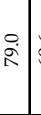 & : & \begin{tabular}{l|l}
0 \\
0 \\
0
\end{tabular} & 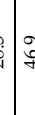 & مे & : & $\begin{array}{l}+ \\
\infty \\
i \infty\end{array}$ & $\begin{array}{l}0 \\
0 \\
0\end{array}$ & 吕: & t. & $\overline{0}$ & 䰚 & $\vec{a}$ & $\mid \begin{array}{l}\overrightarrow{6} \\
\infty\end{array}$ \\
\hline & & 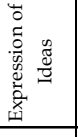 & 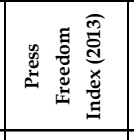 & 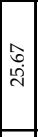 & 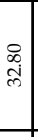 & 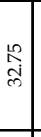 & 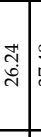 & 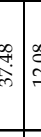 & $\begin{array}{l}8 \\
ن\end{array}$ & 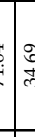 & 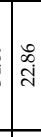 & ते & 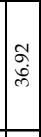 & 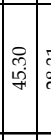 & 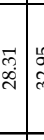 & & 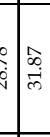 & 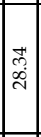 & \begin{tabular}{|l}
1 \\
2 \\
2 \\
\end{tabular} \mid & 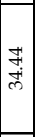 \\
\hline & & 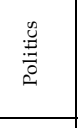 & 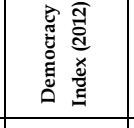 & 表 & 步 & $\begin{array}{r}5 \\
0\end{array}$ & 哭 & $\begin{array}{c}: \\
:\end{array}$ & $\vec{b}$ & $b$ & : & 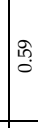 & 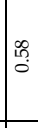 & 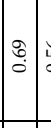 & 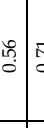 & 5 & 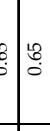 & $\mid \begin{array}{l}\mathscr{B} \\
0 \\
0\end{array}$ & $\mid$ & 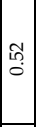 \\
\hline 育 & | & 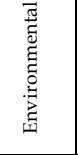 & 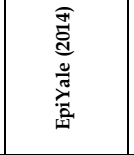 & $\mid \begin{array}{l}\stackrel{t}{0} \\
\dot{q} \\
\mid\end{array}$ & 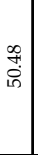 & $\begin{array}{c}5 \\
i \\
i\end{array}$ & $\begin{array}{l}8 \\
8 \\
0\end{array}$ & 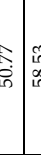 & 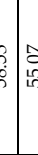 & 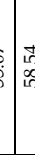 & 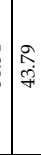 & 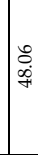 & 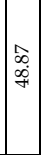 & $\begin{array}{l}0 \\
0 \\
10 \\
10\end{array}$ & 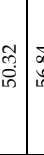 & : & 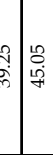 & $\left|\begin{array}{l}\vec{y} \\
0 \\
0 \\
i n\end{array}\right|$ & $\begin{array}{l}\vec{b} \\
\dot{0}\end{array}$ & 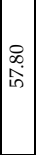 \\
\hline & & 总产 & 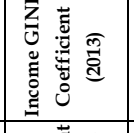 & 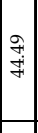 & స్తి & $\begin{array}{l}0 \\
0 \\
\dot{1} \\
\end{array}$ & 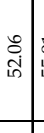 & 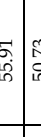 & $\stackrel{?}{?}$ & $\begin{array}{l}\text { ปิ } \\
\text { ฟิ }\end{array}$ & 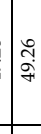 & $\begin{array}{l}\infty \\
\dot{g} \\
\dot{q}\end{array}$ & $\begin{array}{l}\vec{b} \\
\dot{b} \\
\dot{B}\end{array}$ & $\mid \begin{array}{l}10 \\
0 \\
10\end{array}$ & $\begin{array}{lll}0 \\
+7\end{array}$ & $\begin{array}{l}a \\
a \\
a\end{array}$ & 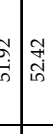 & 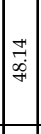 & 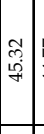 & $\begin{array}{l}\hat{A} \\
\dot{f}\end{array}$ \\
\hline 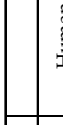 & & 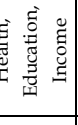 & 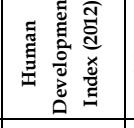 & $\begin{array}{l}\overrightarrow{0} \\
0 \\
0\end{array}$ & 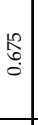 & ֻ̊ & 总 & है & 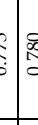 & 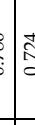 & 递 & 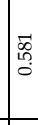 & 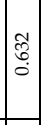 & 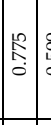 & ه్ & & 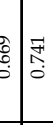 & $\mid \begin{array}{l}\tilde{D} \\
0 \\
0 \\
0\end{array}$ & $\mid$ & 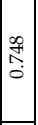 \\
\hline & & & 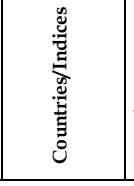 & 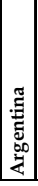 & 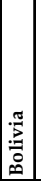 & \begin{tabular}{|l|l|} 
\\
\end{tabular} & $\begin{array}{l}\frac{2}{\tilde{z}} \\
\mathrm{z}\end{array}$ & 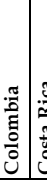 & 量 & : & 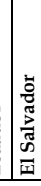 & 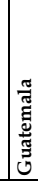 & 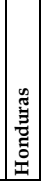 & 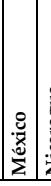 & 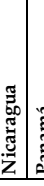 & : & : & 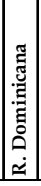 & 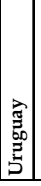 & 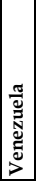 \\
\hline
\end{tabular}


inconsistencies. For example, the freedom of the press' values range between zero and one hundred ( 0 and 100), whereas other indices may range between zero and one $(0,1)$. All of these scales were standardized to range between zero and one $(0,1)$ (Table 2$)$.

Once the data was adjusted, we conducted a principal components analysis, followed by a cluster analysis that grouped together all homogeneous elements (countries with similar characteristics). The results obtained from the first analysis (Table 3) shows:

- The first four factors of the analysis of principal components capture $80 \%$ of data inertia.

- The first factor captures $40.96 \%$ of data inertia and has contributions from the following indices: Human Development Index, Environmental Performance Index, Democracy Index, Gender Inequality, Corruption Perception Index, Prosperity Index, Innovation Index and Globalization Index.

- The second factor is defined by the Press Freedom Index and the Economic Freedom Index, and captures a variance of $17.55 \%$.

- The third factor is integrated by the Happy Planet Index and the Life Satisfaction Index, capturing $11.08 \%$ of data inertia.

- The fourth factor is integrated by the Gini Coefficient, with a variance of $10.35 \%$.

The correlations observed from the principal component analysis (Table 4) through the value-test indicate the following:

- The greater the HDI level, the greater the gender equality, prosperity, innovation and EPI, and the lower the level of perceived corruption.

- The greater the EPI, the greater prosperity and the lower the level of perceived corruption.

- The greater the level of democracy, the greater the freedom of the press, economic freedom, prosperity, innovation and globalization, and the lower the level of perceived corruption.

- The greater the freedom of the press, the greater the economic freedom and globalization. 
व्य

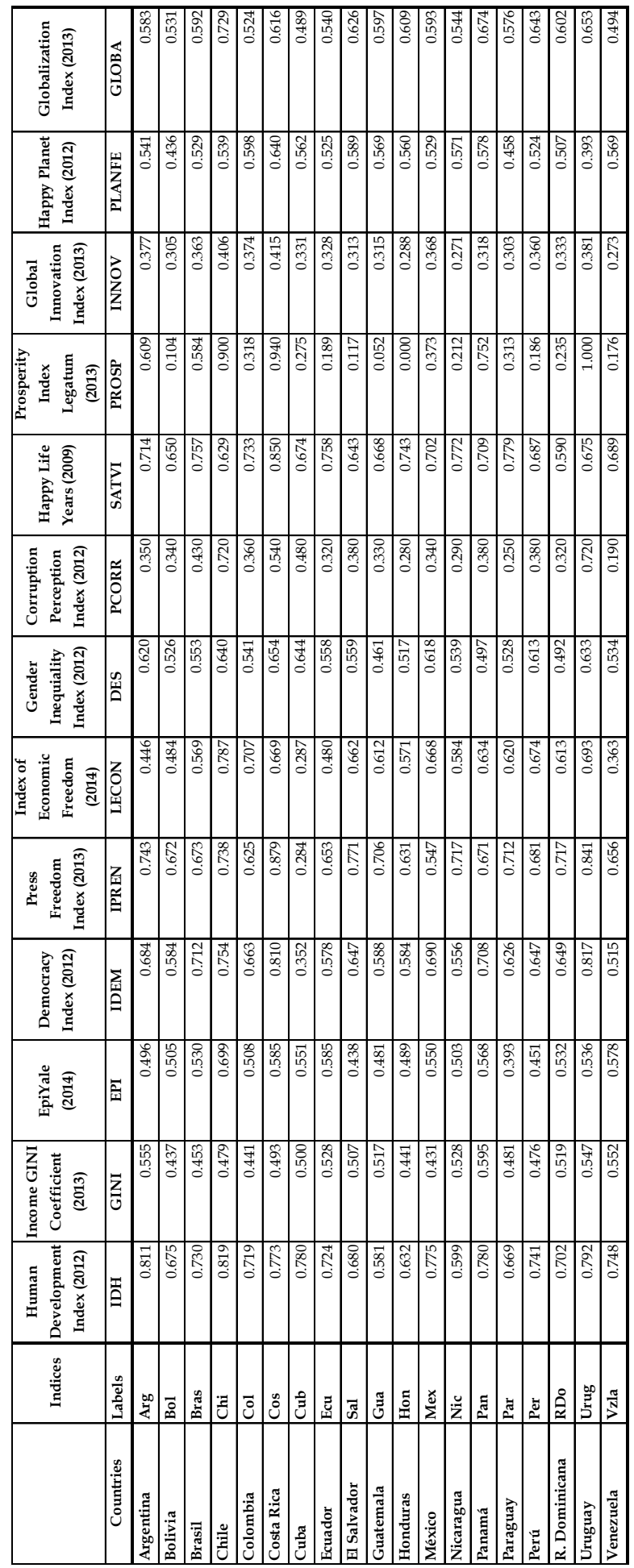


- The greater the economic freedom, the greater innovation, global relations, and the lower the perceived corruption.

- Prosperity has a direct and positive correlation with innovation and globalization. There is also a strong correlation between the last two.

- A low level of perceived corruption stimulates globalization, innovation and prosperity.

Table 3. Inertia factors

\begin{tabular}{|c|c|c|c|}
\hline Number & Eigenvalue & Percentage & $\begin{array}{c}\text { Cumulative } \\
\text { Percentage }\end{array}$ \\
\hline 1 & 5.3247 & 40.96 & 40.96 \\
\hline 2 & 2.2819 & 17.55 & 58.51 \\
\hline 3 & 1.4408 & 11.08 & 69.60 \\
\hline 4 & 1.3461 & 10.35 & 79.95 \\
\hline 5 & 0.9664 & 7.43 & 87.38 \\
\hline 6 & 0.4950 & 3.81 & 91.19 \\
\hline 7 & 0.3797 & 2.92 & 94.11 \\
\hline 8 & 0.3120 & 2.40 & 96.51 \\
\hline 9 & 0.2117 & 1.63 & 98.14 \\
\hline 10 & 0.1174 & 0.90 & 99.04 \\
\hline 11 & 0.0800 & 0.62 & 99.66 \\
\hline 12 & 0.0249 & 0.19 & 99.85 \\
\hline 13 & 0.0194 & 0.15 & 100.00 \\
\hline
\end{tabular}

Source: Own elaboration

The resulting factors of the principal component analysis are determined by the dimensions of the study. The first two factors capture enough variance $(58.51 \%)$, so results will be analyzed using these two factors.

The first factor is integrated by indices in the Potentialities and Synergic Efficiencies dimensions. Within Potentialities, from the 'Capabilities' subcategory the indices that contributed were: Human Development Index and EPI (health, education, income and environment). From the 'Opportunities' category the indices that contributed were: Democracy Index, Gender Equality Index, and Corruption Index (political freedom, freedom of expression and freedom of justice). From the Synergic Efficiencies dimension, the indices that 
contributed were: Prosperity Index, Global Innovation Index and Globalization Index. This factor was denominated Efficiency and Opportunity for the purpose of this study.

Table 4. Correlation Matrix (Values Test)

\begin{tabular}{|c|c|c|c|c|c|c|c|c|c|c|c|c|c|}
\hline & IDH & GINI & EPI & IDEM & IPREN & LECON & DES & PCORR & SATVI & PROSP & INNOV & |PLANFE & GLOBA \\
\hline IDH & 99.99 & & & & & & & & & & & & \\
\hline GINI & 0.86 & 99.99 & & & & & & & & & & & \\
\hline EPI & 2.84 & 0.65 & 99.99 & & & & & & & & & & \\
\hline IDEM & 1.67 & 0.05 & 0.86 & 99.99 & & & & & & & & & \\
\hline IPREN & -0.23 & 1.05 & -0.18 & 4.43 & 99.99 & & & & & & & & \\
\hline LECON & 0.03 & -1.00 & 0.15 & 4.47 & 2.84 & 99.99 & & & & & & & \\
\hline DES & 4.03 & -0.45 & 1.66 & 1.15 & -0.15 & 0.24 & 99.99 & & & & & & \\
\hline PCORR & 2.79 & 0.10 & 2.52 & 2.59 & 1.03 & 1.97 & 3.43 & 99.99 & & & & & \\
\hline SATVI & -0.35 & -0.36 & -0.46 & 0.66 & 0.73 & -0.03 & 0.63 & -0.65 & 99.99 & & & & \\
\hline PROSP & 3.97 & 1.23 & 2.58 & 4.07 & 1.89 & 1.77 & 2.85 & 4.56 & 0.82 & 99.99 & & & \\
\hline INNOV & 3.69 & -0.76 & 1.92 & 3.60 & 1.12 & 2.22 & 3.76 & 4.11 & 0.31 & 4.12 & 99.99 & & \\
\hline PLANFE & -0.24 & 0.30 & 0.80 & -0.54 & -0.42 & -0.05 & -0.07 & -0.81 & 1.45 & -0.33 & 0.13 & 99.99 & \\
\hline GLOBA & 1.24 & 0.48 & 1.02 & 4.05 & 2.53 & 4.32 & 0.81 & 2.93 & -0.85 & 2.74 & 2.22 & -0.32 & 99.99 \\
\hline
\end{tabular}

Source: Own elaboration

The second factor is constituted by two indices from the Opportunities category in the Potentialities dimension. The indices are: Press Freedom and Economic Freedom (freedom of expression and freedom for material satisfaction). This factor was named Liberties for the purpose of this study.

Indices associated with Happiness are neutral in this analysis. Happy Life Years and Happy Planet Index have the greatest correlation amongst themselves and both of them are crucial to the formation of a third factor that we call Happiness. Likewise, the Gini Coefficient (distribution equality) does not have a strong correlation with any other index and forms by itself the fourth factor, which we call Equality.

After carrying out the principal components analysis, a cluster analysis was performed to identify groups of countries with similarities (Statistical report's details in Annex). For this purpose we used the Ward's method. We applied Ward's method with the aim of capturing in the analysis the variability given by the large differences in the region, then, made use of the algorithm of mobile centers and observed the inertia between-groups and within-groups in the different cuts of the dendrogram, as criteria to decide the optimum number of conglomerates. Despite the method used, which 
rests on the variability of the data for grouping with a minimal loss of inertia, the Rand coefficient (Rand 1971) was calculated to compare the consistency of the cluster by applying the methods of conglomeration of the median, nearest neighbor and within-groups linkage, resulting in all cases a coefficient of 0.71 , which is considered a sufficient value for the consistency of the proposed cluster.

In the first stage we analyzed the dendrogram (Figure 1), looking at the data from different perspectives. We identified three clusters of countries split up by the most optimum criteria:

Cluster 1: Argentina, Panama, Cuba, Venezuela and Ecuador

Cluster 2: Mexico, Peru, Brazil, Colombia, Dominican Republic, El Salvador, Bolivia, Paraguay, Honduras, Nicaragua and Guatemala.

Cluster 3: Chile, Uruguay and Costa Rica

Cluster 3 stands out in the dendrogram (Figure 1) as the most robust across the different categories. This indicates that these countries present similar values in their indices. Out of all countries in the study, this group of countries is a very special one.

Figure 1. Dendogram

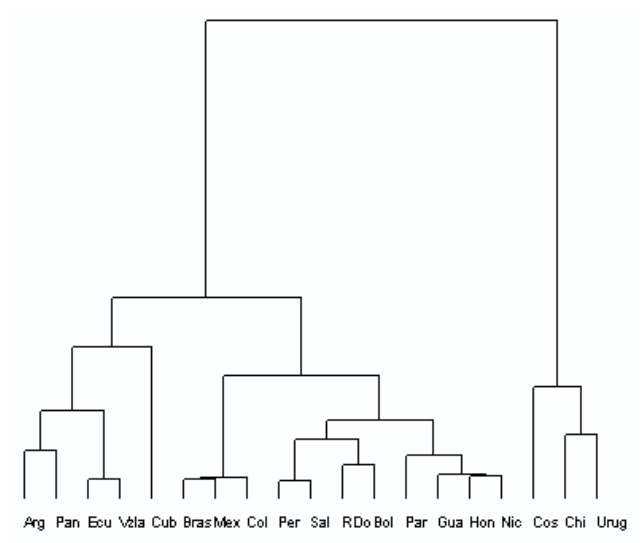

Figure 2 shows the combination of factorial axis and the result of the 
clusters. This figure contains the 'Efficiency and Opportunity' factor as well as the 'Liberties' factor. The location of the clusters and related countries are highlighted in yellow.

Figure 2. Clusters of Countries. First and second factor

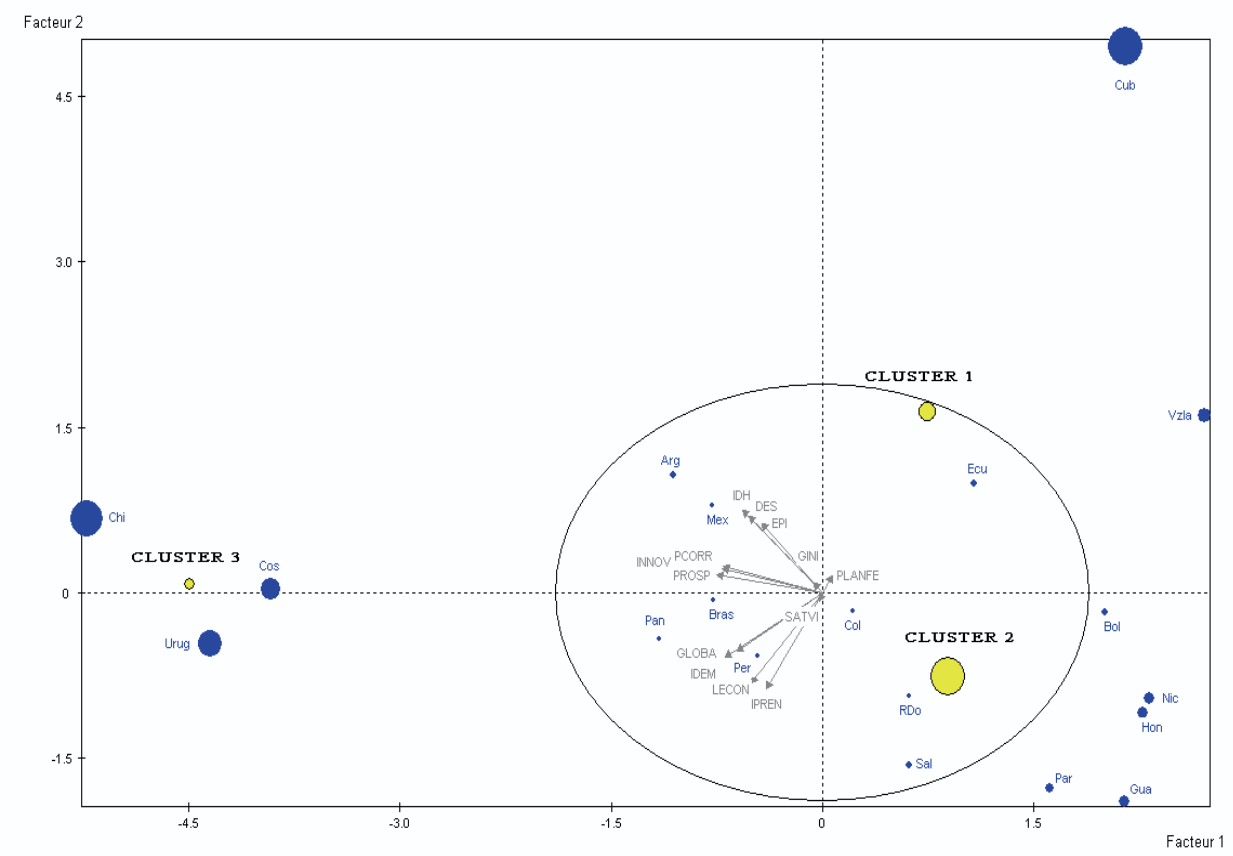

Countries that are close together have greater similarities with one another. Countries located outside the central circle show differences in some of the indices that compose the factors. Countries closer to the origin, such as Colombia in Cluster 2, reflect an average behavior. Countries in circles of larger dimension indicate a greater contribution to the formation of the factors. This explains why Chile, Uruguay and Costa Rica are the countries that best explain the first factor, whereas Cuba, Venezuela, Guatemala and Paraguay best represent the second factor.

An analysis of vectors and their orientation shows that when angles between vectors are acute, it means that indices are highly correlated. That is 
the case of the correlation between Economic Freedom and Press Freedom. Regarding orientation, as long as countries are located in the same direction as the vector, this translates into a high correlation with that index. When the country's direction begins to differ from that of the vector, the correlation decreases. The most extreme case is represented by Ecuador, Venezuela and Cuba with the direction of Economic Freedom and Freedom of Press indices being exactly the opposite of the vector's direction.

The analysis of each of the groups allows us to describe internal characteristics that countries have in common. Also, it allows us to identify countries under extreme positions or positions far from the group's average values.

Cluster 1 (Argentina, Panama, Cuba, Venezuela and Ecuador): Integrated by countries with similar characteristics related to human capabilities (health, education), natural capacities (environmental performance) and equality of income distribution. This group, however, scores very low at the synergic efficiency (global interconnectedness) and at opportunities (freedom of expression, political and economic freedom). Within this group, the most extreme country is Cuba.

Cluster 2 (Mexico, Peru, Brazil, Colombia, Dominican Republic, El Salvador, Bolivia, Paraguay Honduras, Nicaragua and Guatemala): Integrated by countries with similar characteristics related to opportunities (liberty to achieve material satisfaction). This group scores low at capacities (equality of income distribution), human capabilities (health, education and income), natural capacities (environmental performance). Within this group, Nicaragua is located the farthest away from the rest.

Cluster 3 (Chile, Uruguay and Costa Rica): The common element for this group is the countries' high synergic efficiency (collective satisfaction, technological progress and global interconnectedness). They also present high scores at opportunities (justice, liberties and gender equality) and at natural capacities (environmental performance). Within this group, Costa Rica is the farthest away. 
The clusters' most significant characteristics and other elements are presented in Figure 2. The direction of countries in Cluster 3 is very similar to that of the vectors of indices in Factor 1. This means countries in Cluster 3 are associated with high Efficiency and Opportunity, as opposed to vectors of countries in Cluster 2, which reflect low values in this factor.

It is worth mentioning that while the region has close ties due to geographic, historic and cultural reasons, it is not homogeneous. On the contrary, each country has adopted their own policies to address their problems of different sorts. Availability of resources, productivity, culture, tradition, predominant ideology, among others, they are all elements that influence policy-making. Despite this fact, important similarities are observed across different countries.

Countries with low economic freedom also show high levels of corruption and low innovation. Countries associated with indices of equality and capacity not necessarily meet the expected synergic results, unless they have the adequate level of opportunities. Likewise, countries associated with acceptable levels of liberty will not meet the expected synergic results, unless they have the adequate values for capability and equality.

The exercise indicates that the difference between the countries in the region is mainly due to indices of potentialities or appropriate social organization. These are the ones that allow for the combination of capabilities - human and natural - for the pursuit of the desired synergies that ultimately provide the population with a better and sustainable quality of life.

\section{Final Thoughts}

From initial phases of the modern era, when technological progress emerged as the instrument with which nations promote their own economic growth and achieve development, the dynamics of social evolution have evidenced the need for the expansion of the development concept. As such, the notion of development has incorporated dimensions and perspectives that have 
shaped it into a multidimensional concept that includes economic, political, social, cultural, technological, and environmental aspects for present and future generations.

Simultaneously, general perspectives have led the way to specific perspectives, e.g., from global measurements to regional and ultimately to local measurements, from the calculation of averages to a focus on deviations, from single-dimensional indices to multidimensional indices, and from exclusively objective evaluations to the incorporation of subjective perceptions.

Under this scenario, the notion of plans for progress has evolved into a search for satisfaction. On that path, many indices have emerged to facilitate the accomplishment of a demanding challenge: nations' development. Using 13 indices on 19 Latin American countries, this study provides an initial approximation that identifies four clusters of countries classified by their performance in two factors: 'Efficiency and Opportunity' and 'Liberties'.

The collection of data for this research was carried out with few limitations. The indices' databases are open, of free access through the Internet and easily accessible with, in most cases, annual information available. Indices are properly supported with theoretical and methodological foundations for their calculation. We observed that most of the indices are taken from their inception to the dissemination of results by private foundations or by universities. It is common to see associated studies on sensitive issues and controversial political freedoms, civil liberties, corruption, among others. Public entities and above all international agencies - whose members are nation states - are not willing to face the development of some of these indices for the possible political consequences of the upcoming results.

The main obstacle we found stemmed from the absence of data for Cuba in three of the selected indices. This led us to find statistical and methodological alternatives to impute results. This limitation led us also to reflect on the relationship between development/welfare and the availability of statistical information. We start from the affirmation that 
statistical information is a public good that allows capturing the situation of countries on fundamental aspects. The periodic release of information, expressed in indicators and indices, make up a sort of early warning system, showing the areas that require attention, as opposed to those that exhibit strength and are running properly. Based on the above, statistical information should be available to institutions and citizens. As important as the availability are the transparency and reliability of the data. The open and transparent management of indices and indicators is in itself a condition of development. Instead, the opaque management and restricted dissemination of the information is common in countries with governments that violate fundamental rights of its population. Countries that assume the responsibility to develop and disseminate measurements on their own situation surely are those who reach the highest levels of freedom, opportunities and possibilities.

Our study allowed clustering the 19 Latin American countries in 3 groups, showing the importance of opportunities or appropriate social organization to foster synergetic results for a better and sustainable quality of life for their inhabitants. Opportunities or social organization are the key for better social combinations. This does not mean that conditions associated to health, education and income indices are not crucial; however, the homogeneity of these indices across the different countries in the region makes more relevant the ones related to opportunities that social organization offers to the populations. Hence, freedom of political action, freedom of expression, freedom to satisfy material needs, respect for diversity and for otherness, and respect for established rules and norms become the crucial elements.

Finally, this fact supports the most recent theories on the topic of development. It constitutes a clear warning to policy-makers, who, in addition to specific actions that they must undertake, must also contribute by designing a social organization as broad and inclusive as possible, in order to achieve the expected outcome. 


\section{References}

Alaminos, Antonio and Begoña López Monsalve. 2009. “La medición del desarrollo social." Revista OBETS 4: 11-24.

Álvarez Gómez, Julio and Ángel Alonso González. 2006. “Nociones de crecimiento y desarrollo económico." Revista Galega de Economía, 15 (2): 1-10. http://www.usc.es/econo/RGE/Vol15_2/castelan/nb1c. pdf.

Bravo, Carlos Ramiro. 2000. "El pensamiento económico de Jeremy Bentham." Revista de Ciencias Humanas 20. http://www.utp. edu.co/ chumanas/revistas/revistas/rev20/bravo.htm.

Chenery, Hollis B. 1974. Redistribution with growth: policies to improve income distribution in developing countries in the context of economic growth. Oxford: Oxford University Press.

Comisión Sur. 1989. Hacia una nueva forma de medir el desarrollo. Caracas.

Economist Intelligence Unit. 2010. Democracy Index 2010. http://www.eiu. com/public/topical_report.aspx?campaignid=demo2010.

Economist Intelligence Unit. 2011. Democracy Index 2011. Democracy under Stress. http://www.eiu.com/public/topical_report.aspx?campaignid $=$ DemocracyIndex2011.

Ehrlich, Paul R. and John P. Holdren. 1971. "Impact of Population Growth." Science 171 (3977): 1212-1217.

Fund for Peace. 2011. The Failed States Index 2011. Washington: The Fund for Peace. http://www.fundforpeace.org/global/library/cr-11-14-fsfailed statesindex2011-1106p.pdf.

Georgescu-Roegen, Nicholas. 1971. The Entropy Law and the Economic Process. Cambridge: Harvard University Press.

Jacobs, Michael. 1999. "Sustainable development as a contested concept." In Fairness and Futurity, edited by Andrew Dobson, 21-45. New York: Oxford University Press.

KOF Swiss Economic Institute. 2010. KOF Index of Globalization 2010. Zurich: Swiss Federal Institute of Technology. http://globalization.kof. ethz.ch/

Kuznets, Simon. 1955. "Economic Growth and Income Inequality." American Economic Review 45 (1): 1-28.

Levy-Carciente, Sary. 2013. "Reflexiones en torno a desarrollo, política y sociedad: del progreso a la felicidad." Revista Cuadernos del CENDES 30 (82): 1-16. 
Mars, Amanda. 2010. "Midan mi felicidad interior bruta." El País. Nov. 28, 2010. http:/ / www.elpais.com/articulo/sociedad/Midan/felicidad/interi or/bruta/elpepisoc/20101128elpepisoc_1/Tes.

Max-Neef, Manfred A. 1993. Desarrollo a escala humana: conceptos, aplicaciones y reflexiones. Barcelona: Icaria Editorial.

Meadows, Donella H. 1972. The Limits of growth: a Report for the Club of Rome's Project on the Predicament of Mankind. New York: Universe Books

Miller Terry and Kim R. Holmes. 2011. Index of Economic Freedom. New York: Heritage Foundation \& Wall Street Journal.

Mishan, Ezra J. 1967. The Cost of Economic Growth. New York: F. A. Praeger.

Morris, M. David. 1979. Measuring the Condition of the World's Poor. The Physical Quality of Life Index. New York: Pergamon Press.

Munasinghe, Mohan. 1993. Environmental economics and sustainable development. Washington, D.C.: World Bank

Murphy, Mary (ed.). 2009. The Happy Planet Index. London: New Economic Foundation. http://www.happyplanetindex.org/.

Novales Cinca, Alfonso. 2011. "El triángulo del desarrollo económico: Crecimiento, desigualdad y pobreza." Bulletin of EU and US Inflation and Macroeconomic Analysis 200 (Special Issue): 112-120.

Nussbaum, Martha C. 2011. Creating Capabilities: The Human Development Approach. Cambridge: Harvard University Press.

Phélan, Luis Mauricio. 2011. "Revisión de índices e indicadores de desarrollo. Aportes para la medición del buen vivir (Sumak Kawsay)." Obets. Revista de Ciencias Sociales 6 (1): 69-95.

Rand, William M. 1971. "Objective criteria for the evaluation of clustering methods." Journal of the American Statistical Association 66 (336): 846850.

República Bolivariana de Venezuela, RBV. 2007. Proyecto Nacional Simón Bolívar. Primer Plan Socialista - PPS - de Desarrollo Económico y Social de la Nación 2007-2013.

Seers, Dudley. 1972. "What are we trying to measure?" Journal of Development Studies 8 (3): 21-36.

Sen, Amartya. 1999. Development as Freedom. Oxford: Oxford University Press.

SENPLADES. 2009. Plan Nacional para el Buen Vivir 2009-2013. Quito: SENPLADES.

Stanford, Jim. 1999. Economic Freedom for the rest of us. Ottawa: Canadian Center for Policy Alternatives.

Stiglitz, Joseph E., Amartya Sen and Jean-Paul Fitoussi. 2010. Report by the Commission on the Measurement of Economic Performance and Social 
Progress. http://www.stiglitz-sen-fitoussi.fr/documents/rapport_ anglais.pdf.

Talberth, John, Clifford Cobb and Noah Slattery. 2007. Genuine Progress Indicator 2006. A tool for sustainable development. Oakland: Redefining Progress.

UNDP. 2011. Índice de Desarrollo Humano de Hogares e Individuos 2008. Mexic: UNDP.

Veenhoven, Ruut. 2007. "Happy Life Years (HLY)". 'Beyond GDP. Measuring progress, true wealth and well-being of nations' International Conference. Bruxelles: Nov. 19-20, 2007. http: //www2.eur.nl/fsw/research/veenhoven/Pub2000s/2007f-full.pdf. Veenhoven, Ruut. 2009. "Medidas de la Felicidad Nacional Bruta" Intervención Psicosocial 18 (3): 279-299.

World Bank. 1991. World Development Report 1991: The Challenge of Development. https://openknowledge.worldbank.org/handle/ 10986/5974. 


\section{Appendix: Consolidation of the partition using the algorithm of mobile centres}

\section{A. Decomposition of inertia calculated over 10 axes}

Cut of the tree into 2 classes

\begin{tabular}{|c|c|c|c|c|c|c|c|c|}
\hline Inertia & $\begin{array}{l}\text { Inertia } \\
\text { (before) }\end{array}$ & $\begin{array}{l}\text { Inertia } \\
\text { (after) }\end{array}$ & $\begin{array}{l}\text { Objects } \\
\text { (before) }\end{array}$ & $\begin{array}{c}\text { Objects } \\
\text { (after) }\end{array}$ & $\begin{array}{l}\text { Weight } \\
\text { (before) }\end{array}$ & $\begin{array}{l}\text { Weight } \\
\text { (after) }\end{array}$ & $\begin{array}{c}\text { Distances } \\
\text { (before) }\end{array}$ & $\begin{array}{c}\begin{array}{c}\text { Distances } \\
\text { (after) }\end{array} \\
\end{array}$ \\
\hline Inter-class & 3.87251 & 3.87251 & & & & & & \\
\hline \multicolumn{9}{|l|}{ Intra-class } \\
\hline & & & & & & & & \\
\hline Class $1 / 2$ & 7.59188 & 7.59188 & 16 & 16 & 16.00 & 16.00 & 0.72610 & 0.72610 \\
\hline Class 2/ 2 & 1.41130 & 1.41130 & 3 & 3 & 3.00 & 3.00 & 20.65340 & 20.65340 \\
\hline Total & 12.87570 & 12.87570 & & & & & & \\
\hline Quotient (I. inter / I. total) & 0.30076 & 0.30076 & & & & & & \\
\hline
\end{tabular}

Cut of the tree into 3 classes

\begin{tabular}{|c|c|c|c|c|c|c|c|c|}
\hline Inertia & $\begin{array}{c}\text { Inertia } \\
\text { (before) }\end{array}$ & $\begin{array}{r}\text { Inertia } \\
\text { (after) }\end{array}$ & $\begin{array}{r}\text { Objects } \\
\text { (before) }\end{array}$ & $\begin{array}{c}\text { Objects } \\
\text { (after) }\end{array}$ & $\begin{array}{l}\text { Weight } \\
\text { (before) }\end{array}$ & $\begin{array}{l}\text { Weight } \\
\text { (after) }\end{array}$ & $\begin{array}{c}\text { Distances } \\
\text { (before) }\end{array}$ & \begin{tabular}{|c|} 
Distances \\
(after)
\end{tabular} \\
\hline Inter-classes & 5.49551 & 5.49551 & & & & & & \\
\hline \multicolumn{9}{|l|}{ Intra-classe } \\
\hline & & & & & & & & \\
\hline Classe $1 / 3$ & 2.45759 & 2.45759 & 5 & 5 & 5.00 & 5.00 & 4.73898 & 4.73898 \\
\hline Classe $2 / 3$ & 3.51128 & 3.51128 & 11 & 11 & 11.00 & 11.00 & 1.70543 & 1.70543 \\
\hline Classe 3/3 & 1.41130 & 1.41130 & 3 & 3 & 3.00 & 3.00 & 20.65340 & 20.65340 \\
\hline Totale & 12.87570 & 12.87570 & & & & & & \\
\hline & & & & & & & & \\
\hline Quotient (I. inter / I. & 0.42681 & 0.42681 & & & & & & \\
\hline
\end{tabular}

Cut of the tree into 4 classes

\begin{tabular}{|c|c|c|c|c|c|c|c|c|}
\hline Inertia & $\begin{array}{l}\text { Inertia } \\
\text { (before) }\end{array}$ & $\begin{array}{l}\text { Inertia } \\
\text { (after) }\end{array}$ & $\begin{array}{l}\text { Objects } \\
\text { (before) }\end{array}$ & $\begin{array}{c}\text { Objects } \\
\text { (after) }\end{array}$ & $\begin{array}{l}\text { Weight } \\
\text { (before) }\end{array}$ & $\begin{array}{l}\text { Weight } \\
\text { (after) }\end{array}$ & $\begin{array}{c}\begin{array}{c}\text { Distances } \\
\text { (before) }\end{array}\end{array}$ & $\begin{array}{c}\begin{array}{c}\text { Distances } \\
\text { (after) }\end{array} \\
\end{array}$ \\
\hline Inter-classes & 6.71849 & 6.71849 & & & & & & \\
\hline \multicolumn{9}{|l|}{ Intra-classe } \\
\hline Classe & 123467 & 123467 & 4 & 4 & 400 & 400 & 282905 & 382405 \\
\hline $\begin{array}{lll}\text { Classe } & 2 / 4\end{array}$ & 0.00000 & 0.00000 & 1 & 1 & 1.00 & 1.00 & 31.63530 & 31.63530 \\
\hline Classe $3 / 4$ & 3.51128 & 3.51128 & 11 & 11 & 11.00 & 11.00 & 1.70543 & 1.70543 \\
\hline Classe $4 / 4$ & 1.41130 & 1.41130 & 3 & 3 & 3.00 & 3.00 & 20.65340 & 20.65340 \\
\hline Totale & 12.87570 & 12.87570 & & & & & & \\
\hline & & & & & & & & \\
\hline Quotient (I. inter / I. & 0.52180 & 0.52180 & & & & & & \\
\hline
\end{tabular}

The results of the inertia between-groups and within-groups in the different cuts of the dendogram, suggest that the optimum number of conglomerates is three. 


\section{B. Paragons}

Class 1 / 3 Objects: 5

\begin{tabular}{|l|c|c|}
\hline Rank & $\begin{array}{c}\text { Distance to } \\
\text { the center } \\
\text { of the class }\end{array}$ & Label \\
\hline 1 & 2.12433 & Ecu \\
\hline 2 & 6.00599 & Vzla \\
\hline 3 & 6.94750 & Arg \\
\hline 4 & 13.02720 & Pan \\
\hline 5 & 18.58930 & Cub \\
\hline
\end{tabular}

Class 2 / 3 Objects: 11

\begin{tabular}{|l|c|c|}
\hline Rank & $\begin{array}{c}\text { Distance to } \\
\text { the center } \\
\text { of the class }\end{array}$ & Label \\
\hline 1 & 4.20768 & Hon \\
\hline 2 & 4.50380 & Sal \\
\hline 3 & 4.61650 & Per \\
\hline 4 & 5.37893 & Bras \\
\hline 5 & 5.77869 & Col \\
\hline 6 & 6.11332 & RDo \\
\hline 7 & 6.26308 & Gua \\
\hline 8 & 6.51372 & Par \\
\hline 9 & 7.13441 & Bol \\
\hline 10 & 7.74339 & Nic \\
\hline
\end{tabular}

Class 3 / 3 Objects: 3

\begin{tabular}{|l|c|c|}
\hline Rank & $\begin{array}{c}\text { Distance to } \\
\text { the center } \\
\text { of the class }\end{array}$ & Label \\
\hline 1 & 7.05700 & Chi \\
\hline 2 & 8.40115 & Urug \\
\hline 3 & 11.35660 & Cos \\
\hline
\end{tabular}




\section{Characterization by continuous variables of classes in the partition}

Class $1 / 3($ Weight $=5.00$ Objects $=5)$

\begin{tabular}{|l|c|c|c|c|c|c|}
\hline Variables & $\begin{array}{c}\text { Class } \\
\text { Average }\end{array}$ & $\begin{array}{c}\text { General } \\
\text { Average }\end{array}$ & $\begin{array}{c}\text { Standard } \\
\text { deviation } \\
\text { of the }\end{array}$ & $\begin{array}{c}\text { General } \\
\text { Standard } \\
\text { deviation }\end{array}$ & Value-Test & Probability \\
\hline GINI & 0.546 & 0.499 & 0.031 & 0.045 & 2.65 & 0.004 \\
\hline IDH & 0.769 & 0.723 & 0.030 & 0.067 & 1.73 & 0.041 \\
\hline EPI & 0.556 & 0.525 & 0.032 & 0.065 & 1.19 & 0.116 \\
\hline PLANFE & 0.555 & 0.538 & 0.019 & 0.057 & 0.77 & 0.221 \\
\hline DES & 0.571 & 0.565 & 0.054 & 0.057 & 0.27 & 0.394 \\
\hline PROSP & 0.400 & 0.386 & 0.236 & 0.306 & 0.12 & 0.453 \\
\hline SATVI & 0.709 & 0.706 & 0.028 & 0.060 & 0.10 & 0.460 \\
\hline & & & & & & -0.77 \\
\hline INNOV & 0.325 & 0.338 & 0.033 & 0.041 & 0.220 \\
\hline PCORR & 0.344 & 0.389 & 0.094 & 0.136 & -0.85 & 0.199 \\
\hline GLOBA & 0.556 & 0.590 & 0.068 & 0.060 & -1.45 & 0.073 \\
\hline IPREN & 0.601 & 0.680 & 0.162 & 0.119 & -1.68 & 0.047 \\
\hline IDEM & 0.567 & 0.640 & 0.129 & 0.104 & -1.77 & 0.038 \\
\hline LECON & 0.442 & 0.585 & 0.117 & 0.121 & -3.00 & 0.001 \\
\hline
\end{tabular}

Class 2/3 $($ Weight $=11.00$ Objects $=11)$

\begin{tabular}{|l|c|c|c|c|c|c|}
\hline Variables & $\begin{array}{c}\text { Class } \\
\text { Average }\end{array}$ & $\begin{array}{c}\text { General } \\
\text { Average }\end{array}$ & $\begin{array}{c}\text { Standard } \\
\text { deviation } \\
\text { of the } \\
\text { class }\end{array}$ & $\begin{array}{c}\text { General } \\
\text { Standard } \\
\text { deviation }\end{array}$ & Value-Test & Probability \\
\hline LECON & 0.615 & 0.585 & 0.060 & 0.121 & 1.21 & 0.113 \\
\hline & & & & & & \\
\hline IPREN & 0.677 & 0.680 & 0.057 & 0.119 & -0.10 & 0.460 \\
\hline SATVI & 0.702 & 0.706 & 0.058 & 0.060 & -0.35 & 0.363 \\
\hline PLANFE & 0.534 & 0.538 & 0.049 & 0.057 & -0.36 & 0.360 \\
\hline IDEM & 0.631 & 0.640 & 0.047 & 0.104 & -0.42 & 0.338 \\
\hline GLOBA & 0.585 & 0.590 & 0.036 & 0.060 & -0.42 & 0.336 \\
\hline INNOV & 0.327 & 0.338 & 0.034 & 0.041 & -1.37 & 0.086 \\
\hline PCORR & 0.336 & 0.389 & 0.049 & 0.136 & -1.94 & 0.026 \\
\hline DES & 0.541 & 0.565 & 0.044 & 0.057 & -2.10 & 0.018 \\
\hline GINI & 0.476 & 0.499 & 0.035 & 0.045 & -2.59 & 0.005 \\
\hline PROSP & 0.227 & 0.386 & 0.158 & 0.306 & -2.59 & 0.005 \\
\hline EPI & 0.489 & 0.525 & 0.044 & 0.065 & -2.78 & 0.003 \\
\hline IDH & 0.682 & 0.723 & 0.057 & 0.067 & -3.00 & 0.001 \\
\hline
\end{tabular}


Class 3/3 (Weight $=3.00$ Objects $=3$ )

\begin{tabular}{|l|c|c|c|c|c|c|}
\hline Variables & $\begin{array}{c}\text { Class } \\
\text { Average }\end{array}$ & $\begin{array}{c}\text { General } \\
\text { Average }\end{array}$ & $\begin{array}{c}\text { Standard } \\
\text { deviation } \\
\text { of the }\end{array}$ & $\begin{array}{c}\text { General } \\
\text { Standard } \\
\text { deviation }\end{array}$ & Value-Test & Probability \\
\hline PCORR & 0.660 & 0.389 & 0.085 & 0.136 & 3.65 & 0.000 \\
\hline PROSP & 0.947 & 0.386 & 0.041 & 0.306 & 3.36 & 0.000 \\
\hline INNOV & 0.401 & 0.338 & 0.014 & 0.041 & 2.78 & 0.003 \\
\hline IDEM & 0.794 & 0.640 & 0.028 & 0.104 & 2.70 & 0.003 \\
\hline DES & 0.642 & 0.565 & 0.009 & 0.057 & 2.52 & 0.006 \\
\hline GLOBA & 0.666 & 0.590 & 0.047 & 0.060 & 2.33 & 0.010 \\
\hline EPI & 0.607 & 0.525 & 0.068 & 0.065 & 2.32 & 0.010 \\
\hline IPREN & 0.819 & 0.680 & 0.060 & 0.119 & 2.16 & 0.015 \\
\hline LECON & 0.716 & 0.585 & 0.051 & 0.121 & 1.98 & 0.024 \\
\hline IDH & 0.795 & 0.723 & 0.019 & 0.067 & 1.97 & 0.024 \\
\hline SATVI & 0.718 & 0.706 & 0.095 & 0.060 & 0.35 & 0.362 \\
\hline GINI & 0.506 & 0.499 & 0.029 & 0.045 & 0.30 & 0.382 \\
\hline & & & & & & \\
\hline PLANFE & 0.524 & 0.538 & 0.101 & 0.057 & -0.44 & 0.329 \\
\hline
\end{tabular}

D. After consolidation - Distribution of active individuals in classes of the partition

\begin{tabular}{|l|c|c|}
\hline Number & Object & Class \\
\hline 1 & Arg & 1 \\
\hline 2 & Bol & 2 \\
\hline 3 & Bras & 2 \\
\hline 4 & Chi & 3 \\
\hline 5 & Col & 2 \\
\hline 6 & Cos & 3 \\
\hline 7 & Cub & 1 \\
\hline 8 & Ecu & 1 \\
\hline 9 & Sal & 2 \\
\hline 10 & Gua & 2 \\
\hline 11 & Hon & 2 \\
\hline 12 & Mex & 2 \\
\hline 13 & Nic & 2 \\
\hline 14 & Pan & 1 \\
\hline 15 & Par & 2 \\
\hline 16 & Per & 2 \\
\hline 17 & RDo & 2 \\
\hline 18 & Urug & 3 \\
\hline 19 & Vzla & 1 \\
\hline
\end{tabular}

